\title{
Variation Among Orchardgrass (Dactylis glomerata) Germplasm for Choke Prevalence Caused by Epichloë typhina
}

B. Shaun Bushman, ${ }^{\dagger}$ USDA-ARS Forage and Range Research Laboratory, Logan, UT 84322; Devesh Singh and Robin Lamp, Barenbrug USA, Tangent, OR 97389; Carolyn A. Young and Nikki D. Charlton, Noble Research Institute, LLC, Ardmore, OK 73401; Joseph G. Robins, USDA-ARS Forage and Range Research Laboratory, Logan, UT 84322; and Nicole Anderson, Department of Crop and Soil Science, Oregon State University, Corvallis, OR 97331

\begin{abstract}
Orchardgrass, or cocksfoot (Dactylis glomerata L.), is a cool-season forage grass susceptible to the choke disease caused by Epichloë typhina. Choke has been reported in orchardgrass seed production fields across the temperate regions of the world, but fungicides have not been efficacious in reducing choke incidence or prevalence. To assess the potential for genetic resistance or tolerance of orchardgrass to choke, we evaluated the variation in orchardgrass cultivars and accessions for choke prevalence and characterized infected plants for endophyte secondary metabolite and mating type gene presence. Significant variation was detected across years and locations. Choke

prevalence did not always increase with the age of the stand, nor did choke prevalence correlate with flowering time or swathing time of the entries. Both mating types of E. typhina were detected in approximately equal proportions, and no evidence for loline, ergot alkaloid, or indole-diterpene biosynthesis was found. Plants with multiple infected tillers often showed more than one mating type present in the plant, indicating multiple infection events rather than a single infection event that spread to multiple tillers. Both accessions and cultivars with significant choke, and no choke, were detected, which constitute sources of germplasm for further testing and breeding.
\end{abstract}

Orchardgrass, or cocksfoot (Dactylis glomerata L.), is one of the top four cool-season forage grasses worldwide (Stewart and Ellison 2010) but is susceptible to the choke disease. Choke is caused by Epichlö typhina, an inconspicuous systemic fungal endophyte in vegetative tissues that initiates its own sexual cycle during host flowering (Craven et al. 2001). Upon initiation of the sexual cycle, the E. typhina surrounds the host's immature inflorescence before it can emerge from the surrounding leaf sheaths and prevents (chokes) its further development and seed set. Choke has been reported in orchardgrass seed production and other fields in the United States, Europe, and Asia (Cagaš and Macháč 2012; Large 1954; Li et al. 2009; Pfender and Alderman 1999). In Oregon's Willamette Valley, incidence of choke was first reported in 1996 (Pfender and Alderman 1999), with subsequent seed yield losses growing from $9 \%$ to over $30 \%$ (Pfender and Alderman 2006).

Multiple reports have studied the occurrence, spread, and possible fungal infection routes of choke on orchardgrass, as well as vectors that might aid in fertilization of the sexual fungus. What has emerged is a complicated and unclear pattern. Once choke is detected within a field, it appears to pervade in a quadratic response (Pfender and Alderman 2006). The scale and spread of choke are not completely consistent with small-scale plant wounding (Alderman 2013; Leyronas and Raynal 2008), such that wounding caused by swathing during orchardgrass seed harvest and while ascospores are abundant has remained a likely cause for fungal spread (Western and Cavett 1959).

Throughout the vegetative plant growth, the endophyte remains inconspicuous, growing slowly between the intercellular spaces of the plant host and maintaining growth primarily near the crown of the plant (Christensen et al. 2008; Kirby 1961). The intercellular growth of the endophyte changes abruptly upon an unknown signal

${ }^{\dagger}$ Corresponding author: B. S. Bushman;

E-mail: shaun.bushman@ars.usda.gov

Funding: The authors thank the Oregon State University Agriculture Research Foundation and the Oregon Seed Council for funding.

*The $\boldsymbol{e}$-Xtra logo stands for "electronic extra" and indicates that two supplementary figures are published online.

Accepted for publication 13 August 2018.

This article is in the public domain and not copyrightable. It may be freely reprinted with customary crediting of the source. The American Phytopathological Society, 2019. or signals from the plant at flowering, whereupon the endophyte is able to ramify through the host, developing stromata that engulf (choke) the developing seed heads. E. typhina in orchardgrass is considered aggressive, in that each endophyte-infected tiller will choke, and those tillers without choke are endophyte-free (Schardl et al. 2009). This aggressive nature is in contrast to the related E. festucae, in which asymptomatic tillers of host grasses (e.g., Festuca rubra L.) can be infected. Because the E. typhina endophyte is only conspicuous when orchardgrass begins to flower, fungicide treatments have had little or no effect (Pfender and Alderman 2003). Additionally, E. typhina is heterothallic and requires fertilization with the opposite mating type to develop and release ascospores that can lead to horizontal transmission. Although several insects have been proposed as travel vectors for fungal fertilization, none have been shown to account for the majority of fertilization of the fungus (Hoffman and Rao 2014; Rao et al. 2012; Rao and Baumann 2004). Thus, many questions still exist surrounding infection, growth, and fertilization, and no efficacious treatment or control has yet been found.

Breeding of disease-tolerant or -resistant cultivars is a lengthy process, but when less expensive or effective management options are lacking this approach holds merit. In the case of choke and orchardgrass, mechanisms of possible tolerance or resistance would be difficult to define but may include gene products that prevent or dilute the plant signal that induces the fungal sexual stage, phenology mechanisms to avoid times when fungal spores are prevalent, or plant structure or secondary metabolites that limit fungal entry or survival in mature tissues. Although the explanatory causes of choke would be difficult to define, resistance or tolerance can be detected in replicated field trials by a lack or paucity of choke in replicated entries over time. The objective of our research was to determine if there is variation for the percentage of infected plants among orchardgrass collections and varieties, to characterize E. typhina and the mating type frequency among these collections and varieties, and to identify germplasm sources that are less symptomatic of choke for further evaluation and plant breeding.

\section{Materials and Methods}

Forty-eight orchardgrass varieties and wildland collections (hereafter called entries) were planted in two sites: one near Albany, OR, at $44^{\circ} 37^{\prime} 32.86^{\prime \prime} \mathrm{N} / 122^{\circ} 55^{\prime} 57.63^{\prime \prime} \mathrm{W}$, and one near Corvallis, OR, at $44^{\circ} 30^{\prime} 53.30^{\prime \prime} \mathrm{N} / 123^{\circ} 13^{\prime} 18.75^{\prime \prime} \mathrm{W}$. The entries represented the wide range of flowering times present in orchardgrass and germplasm from Mediterranean as well as Continental origins (Table 1). Each 
location was planted with three replications of 16 plant plots, in a randomized complete block design. Seedlings of each entry were germinated in Logan, UT, and transplanted at the two Willamette Valley, OR, locations in the summer of 2012. Plots were maintained thereafter with fertilizer, pesticide for rust diseases, and herbicide as needed and directed in the Oregon State University orchardgrass fertilizer guide (Doerge et al. 2000) and the Pacific Northwest weed and pest management handbooks (https://pnwhandbooks.org/). Choke prevalence data were collected from 2013 through 2016. Plant mortality was recorded prior to choke scoring each year. Temperature and precipitation data were extracted from the Oregon State University PRISM database (prism.oregonstate.edu) for Linn County, OR, where both research plots reside. Spring temperature data comprised average monthly maximum and minimum temperatures from March through May of each year, and spring precipitation was the sum of precipitation across those three months.
For each year of data collection, heading and swathing dates were determined at the Albany site (Table 1). Heading dates of individual plants were recorded as the day from January first when three panicles emerged from the boot and were recorded as the date when $50 \%$ of the plants in a plot had headed. Swathing occurs after seed has ripened and comprises cutting and laying down the tillers prior to combine harvesting. Entry plots were swathed at both locations on the same day but were based on maturity of seed at the Albany location and when seed moisture was at 42 to $46 \%$, such that swathing dates were also recorded as the number of days from January 1. Plant material was discarded 1 week after swathing. Choke prevalence scoring occurred at anthesis and was recorded as the number of plants in each 16-plant plot that had stromata covering one or more panicles (Fig. 1). All plots were scored twice, by different people, to ensure accuracy. To account for plant mortality within plots, the number of plants with infected tillers was divided by the total number of plants

Table 1. Orchardgrass cultivars and accessions evaluated for choke prevalence ${ }^{\mathrm{a}}$

\begin{tabular}{|c|c|c|c|c|c|c|}
\hline Entry & Source/information & Growth type & Heading date & Swathing date & Mortality (Albany) & Mortality (Corvallis) \\
\hline AC Killarney & Agri-Food Canada & Continental & 126.1 & 193.0 & 1.8 & 24.4 \\
\hline Baraula & Barenbrug & Continental & 127.2 & 188.7 & 2.5 & 15.9 \\
\hline Barexcel & Barenbrug & Continental & 112.5 & 182.0 & 1.1 & 19.1 \\
\hline Baridana & Barenbrug & Continental & 118.3 & 183.7 & 1.5 & 13.0 \\
\hline Barlegro & Barenbrug & Continental & 121.1 & 183.3 & 5.1 & 22.4 \\
\hline Barlemas & Barenbrug & Continental & 107.9 & 178.0 & 0.9 & 32.6 \\
\hline Benchmark Plus & FFR Cooperative & Continental & 114.9 & 180.3 & 0.4 & 14.7 \\
\hline Crown Royale & Grassland Oregon & Continental & 113.7 & 182.0 & 0.7 & 9.9 \\
\hline Dg12R01 & Barenbrug & Continental & 129.2 & 195.3 & 3.1 & 11.1 \\
\hline DglGRL & Barenbrug & Continental & 108.1 & 177.3 & 2.6 & 14.5 \\
\hline Gr. Tekapo & Grasslandz Tech. Lmtd. & Unknown & 114.0 & 182.0 & 15.0 & 21.6 \\
\hline Harunemidori & NARCH, Japan & Continental & 114.8 & 179.3 & 1.7 & 5.1 \\
\hline Icon & Forage first & Continental & 110.1 & 178.7 & 1.6 & 9.3 \\
\hline Intensiv & Barenbrug & Continental & 128.5 & 184.0 & 0 & 16.1 \\
\hline NFOG-101 & Noble Res. Inst. & Continental & 107.0 & 180.7 & 35.6 & 25.8 \\
\hline PI 189142 & Netherlands & Continental & 116.1 & 186.7 & 0 & 17.4 \\
\hline PI 189388 & New Zealand & Continental & 114.7 & 182.0 & 2.9 & 18.2 \\
\hline PI 217416 & Denmark & Continental & 112.6 & 181.0 & 1.4 & 26.4 \\
\hline PI 223250 & Afghanistan & Continental & 107.2 & 179.3 & 3.9 & 20.9 \\
\hline PI 231484 & Algeria & Continental & 116.1 & 186.7 & 0.7 & 4.9 \\
\hline PI 235471 & Switzerland & Continental & 117.5 & 183.7 & 3.1 & 18.9 \\
\hline PI 237602 & Portugal & Continental & 119.7 & 195.3 & 33.6 & 53.7 \\
\hline PI 237610 & Iran & Continental & 116.3 & 184.7 & 0 & 3.2 \\
\hline PI 242800 & Turkey & Unknown & 107.8 & 178.7 & 25.8 & 55.2 \\
\hline PI 250928 & Iran & Continental & 116.5 & 181.7 & 1.5 & 21.4 \\
\hline PI 253966 & Iraq & Continental & 105.8 & 179.7 & 8.2 & 18.6 \\
\hline PI 292592 & Israel & Unknown & 105.6 & 182.3 & 46.4 & 48.8 \\
\hline PI 308542 & Colombia & Unknown & 104.4 & 174.0 & 4.3 & 16.3 \\
\hline PI 311374 & Spain & Mediterranean & 111.8 & 183.3 & 46.0 & 47.9 \\
\hline PI 311402 & Spain & Mediterranean & 120.3 & 186.0 & 2.0 & 20.1 \\
\hline PI 368879 & Portugal & Mediterranean & 113.3 & 183.0 & 29.7 & 48.3 \\
\hline PI 371948 & Bulgaria & Continental & 108.4 & 180.3 & 2.8 & 11.2 \\
\hline PI 499409 & China & Continental & 136.9 & 198.0 & 4.2 & 53.3 \\
\hline PI 516543 & Morocco & Mediterranean & 112.6 & 185.7 & 44.2 & 55.7 \\
\hline PI 527484 & France & Continental & 112.0 & 181.0 & 17.2 & 28.6 \\
\hline PI 538922 & Russia & Continental & 127.7 & 198.0 & 0.2 & 29.0 \\
\hline PI 577042 & Yugoslavia & Continental & 117.6 & 181.3 & 3.3 & 16.9 \\
\hline PI 578584 & Morocco & Mediterranean & 127.2 & 188.7 & 45.2 & 63.6 \\
\hline PI 578597 & Israel & Unknown & 108.7 & 178.0 & 16.3 & 36.4 \\
\hline PI 578603 & Cyprus & Mediterranean & 112.4 & 183.0 & 40.0 & 68.5 \\
\hline PI 578610 & Algeria & Mediterranean & 117.7 & 189.3 & 54.9 & 73.5 \\
\hline PI 598862 & Morocco & Mediterranean & 112.6 & 184.0 & 47.5 & 51.8 \\
\hline PI 632495 & Tunisia & Mediterranean & 113.2 & 191.3 & 48.0 & 76.1 \\
\hline PI 634258 & Albania & Unknown & 111.4 & 184.7 & 6.2 & 14.4 \\
\hline PI 636581 & China & Continental & 128.0 & 195.3 & 2.4 & 21.4 \\
\hline Potomac & Check Cultivar & Continental & 115.2 & 179.3 & 0.8 & 4.6 \\
\hline Syn9914 & Barenbrug & Continental & 120.2 & 183.0 & 0.3 & 13.0 \\
\hline Toyomidori & NARCH, Japan & Continental & 139.9 & 198.0 & 7.5 & 13.8 \\
\hline $\operatorname{LSD}(0.05)$ & & & 2.9 & 3.2 & 6.8 & 13.0 \\
\hline
\end{tabular}

${ }^{\mathrm{a}} \mathrm{LSD}=$ least significant difference. 
(maximum 16) in each plot, and choke prevalence data were recorded as the percent of plants exhibiting choke per entry.

To characterize the E. typhina strains and mating types, orchardgrass tissue containing E. typhina stromata was collected individually from infected plants immediately below the stroma present on a reproductive tiller. During each collection, reproductive tillers without choke were also collected as controls. In 2014, 129 infected plants were randomly sampled from both locations; in 2015, all infected plants were sampled from both locations; and in 2016, all infected plants were sampled from the Albany location. Also, in 2016, eight plants with at least 10 choked tillers were evaluated by polymerase chain reaction (PCR) to determine if endophyte variation existed within a plant. DNA was extracted from the samples using the Qiagen MagAttract Kit (Qiagen, Valencia, CA). PCR was performed with eight Epichloë-specific primer sets to evaluate the fungal diversity based on the following genes: tefA encoding the translation elongation factor-1- $\alpha$, perA encoding peramine synthetase and using primer sets to different $\mathrm{T} 2$ and $\mathrm{R}$ protein domains, lolC encoding the first step of loline production, dmaW encoding dimethylallyl tryptophan synthase in the first step in ergot alkaloid production, $i d t G$ encoding the first step of indole diterpene production, and $m t A C$ and $m t B A$ mating type genes. PCR conditions and primer sequences of these genes were previously published in Charlton et al. (2014).

Heading date, plant mortality, swathing date, and choke prevalence were analyzed as nearest-neighbor mixed models using the ASReml-R package in R (Butler et al. 2009; R Core Team 2013). For each trait, years, locations, orchardgrass populations, and their interactions were modeled as fixed effects. Blocks within locations were modeled as random effects. The analysis also modeled the covariance associated with repeated measures of the plots across years and the spatial variation within each location based on the locations of plots in the row and column field structure (Smith and Casler 2004). For the fixed effects the model estimated best linear unbiased estimates. Rank and Pearson correlations were estimated using the CORR procedure of SAS (SAS Institute 2011). Discriminant analysis was used to determine if groups of entries categorized by growth type, heading date, or swathing date would be able to be discriminated by choke prevalence. First the STEPDISC procedure in SAS was used to determine if choke prevalence at either or both of the locations was an appropriate variable. Then the DISCRIM procedure of SAS with pooled variance was used to test the significance of the discriminatory variables.

\section{Results}

The effect of year, year by location, and year by entry were each significant at $P<0.001$. Although no choke data were collected during the 2012 establishment year, years 2013 to 2016 had overall choke levels significantly greater than zero, except 2013 at the Albany location (Fig. 2). Years 2014 and 2016 had relatively higher choke prevalence, whereas 2013 and 2015 showed less choke (Fig. 2). Concerning the year by entry effect, Spearman rank correlations of choke prevalence in entries were highly significant (Table 2), such that further analyses for choke prevalence were combined across years. Concerning the year by location effect, the rank correlations between year and location ranged from $r=0.40$ to $0.50(P<0.01)$, significant yet moderate to the extent that both magnitude and rank changes occurred between the locations. Therefore, further analyses for choke prevalence were conducted separately by location.

Because climate in the spring season might affect the E. typhina infection rate, temperature and precipitation data were collected for each year across the months of March to May (Fig. 3). Although the average minimum and average maximum temperatures did not

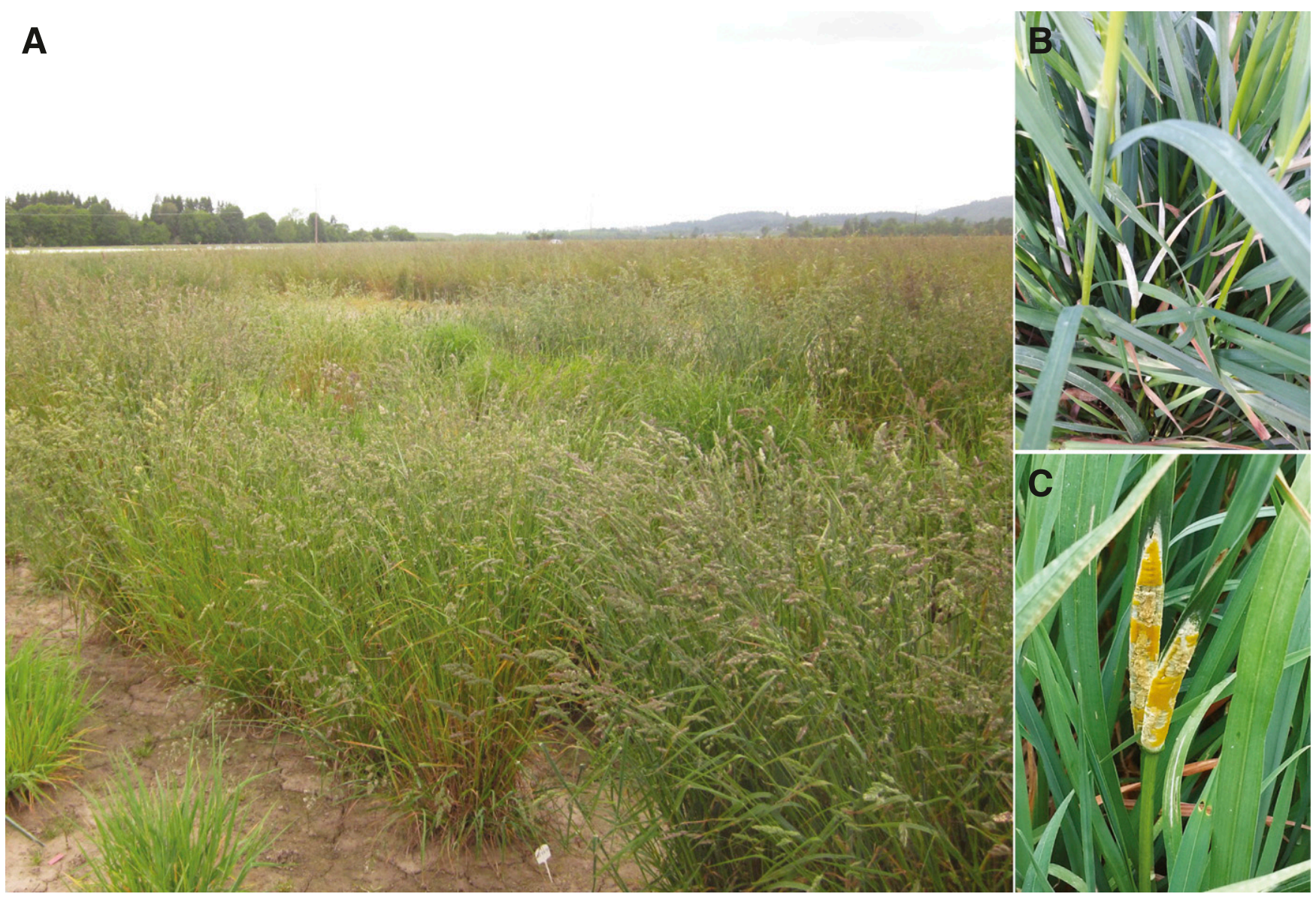

Fig. 1. A, Replicated field plots of orchardgrass near Albany, OR, at the time of choke data collection. B, Stroma (white) surrounding the immature inflorescences on an Epichloë typhina-infected plant. C, Fertilized stroma. 
vary appreciably, the spring precipitation varied (Fig. 3) and reflected the choke prevalence (Figs. 2 and 3 ).

At both locations, PI 223250 exhibited no choke over the course of the experiment, whereas four entries showed choke prevalence significantly greater than zero (Fig. 4). At the Albany location, four entries exhibited no choke over the course of the experiment, whereas 17 entries, including 9 of the 13 cultivars, had a prevalence significantly greater than zero (Fig. 4). At the Corvallis location, 14 entries had no choke, whereas 7 had choke prevalence significantly greater than zero (Fig. 4). The 'Baraula' cultivar had a particularly high percentage of choke, exhibiting choke even in year 2 (data not shown) and having 40 and $57 \%$ of plants infected across the 4 years at the two locations. The significance detected in spatial analysis did not reveal any specific patterns of choke spread but was rather clustered approximate to Baraula entries (darker blocks, Supplementary Fig. S1). Entries with little or no choke prevalence across the 4 years mainly included wildland collections: PI 223250, PI 292592, PI 578603, PI 578584, and PI 371948. Of the cultivars tested, 'AC Killarney', 'Barlegro', 'Grasslands Tekapo', and 'Harunemidori' had the lowest choke prevalence.

To estimate the relationship of choke prevalence to heading date or swathing date, correlations were computed. Heading dates were highly correlated across years, whereas swathing dates were not (Table 2). Heading dates ranged from 104 (April 15) to 140 (May 21) days from January 1 but were only moderately correlated with choke prevalence $(r=0.29$ at Albany and $r=0.20$ at Corvallis, both $P<0.05)$. When the late-heading cultivar Baraula was removed from analysis, the correlations between heading date and choke prevalence at the two locations were not significant. Swathing dates ranged from 174 (June 23) to 198 (July 18) days from January 1, were correlated with heading dates at $r=0.75(P<0.001)$, but were not correlated with choke prevalence at either location. Based on discriminant analyses, choke prevalence was not significant in its ability to discriminate heading or swathing dates at either location.

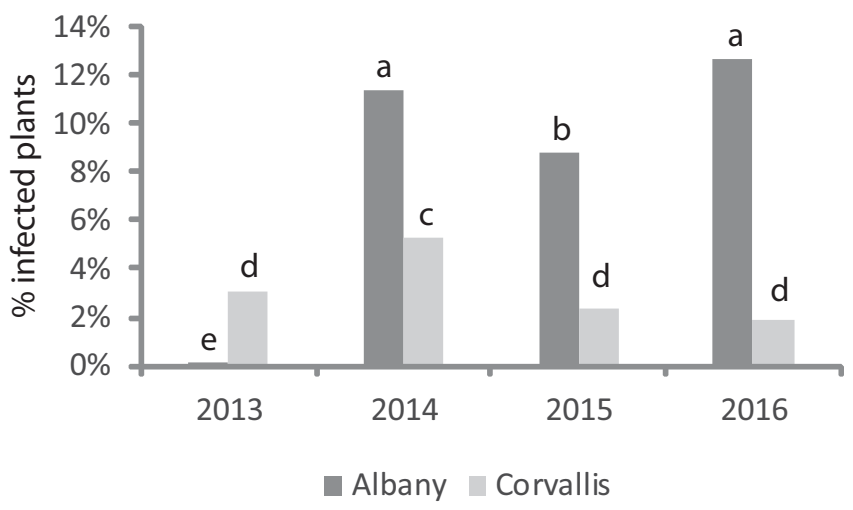

Fig. 2. The overall percent of Epichloë typhina-infected orchardgrass plants at two locations in Oregon, from 2013 to 2016.

Table 2. Spearman rank correlations across years for the percent of Epichloë typhina-infected plants, plot heading date (Albany location only), and plot swathing date (Albany location only) ${ }^{\mathrm{a}}$

\begin{tabular}{llccc}
\hline Year & Parameter & $\mathbf{2 0 1 3}$ & $\mathbf{2 0 1 4}$ & $\mathbf{2 0 1 5}$ \\
\hline 2014 & Choke prevalence & $0.71^{* *}$ & $\ldots$ & $\ldots$ \\
& Heading date & $0.90^{* *}$ & $\ldots$ & $\ldots$ \\
& Swathing date & $-0.43^{* *}$ & $\ldots$ & $\ldots$ \\
2015 & Choke prevalence & $0.55^{* *}$ & $0.84^{* *}$ & $\ldots$ \\
& Heading date & $0.84^{* *}$ & $0.92^{* *}$ & $\ldots$ \\
& Swathing date & $0.69^{* *}$ & -0.17 & $\ldots$ \\
& Choke prevalence & $0.43^{* *}$ & $0.65^{* *}$ & $0.74^{* *}$ \\
& Heading date & NA & NA & NA \\
& Swathing date & NA & NA & NA \\
\hline a NA $=$ not applicable & & &
\end{tabular}

${ }^{\text {a }} \mathrm{NA}=$ not applicable
To determine if summer dormant/winter active Mediterranean orchardgrass ecotypes varied in choke prevalence compared with summer active/winter dormant Continental orchardgrass ecotypes, discriminant analysis was further conducted. The cultivars and accessions were grouped into Continental (33 entries), Mediterranean (nine entries), and unknown (six entries) based on country of origin (Table 1). Stepwise discriminant analysis identified choke prevalence from both Corvallis and Albany locations for inclusion into the model to discriminate ecotype, with a Wilk's lambda value of $\mathrm{F}_{4,84}=2.36(P=0.06)$. Using choke prevalence as an indicator, the unknown category was separated with $100 \%$ accuracy, the Mediterranean ecotypes were grouped into either Mediterranean or unknown categories, but the Continental ecotypes were placed into all three categories and thus poorly discriminated from the other two ecotypes (Table 3 ).

In total, 560 individual plants were tested by PCR to evaluate the endophyte within the study fields. The endophyte was only detected in the choked tillers, whereas tillers with developing inflorescences were endophyte-free. All infected samples across both locations were consistent and tested positive for the tefA, perA-T2, and mating type markers (Supplementary Fig. S2). The endophyte-infected orchardgrass samples showed no evidence of the potential to produce lolines, ergot alkaloids, or indole-diterpenes, because the genes encoding early pathway steps were not detected. For mating types, either $m t A C$ or $m t B A$ amplified per individual tiller sample, and approximately equal frequencies of mating types were detected at the two locations (Table 4). In 2016, plants with more than 10 individual choked tillers were selected to determine if a plant could have multiple infections, which would be evidenced by the presence of more than one mating type associated with a single plant. Of the eight individual plants tested, four had mixed infections in which both $m t A C$ and $m t B A$ were present. To validate this result, we identified 98 individual plants from 16 plant lines that were tested in both 2015 and 2016. Of these infected plants, $23 \%$ of the samples showed both mating types (Table 5).

\section{Discussion}

Although choke prevalence varied by year, it did not necessarily increase each year. Previous studies have seen similar results (Cagaš and Macháč 2012; Leyronas and Raynal 2008) and have found that moisture and cool temperatures were necessary for ascospores germination (Alderman 2013). Because of such, we extracted the spring seasonal temperature and precipitation data prior to each orchardgrass flowering season to test for possible correlations of choke prevalence and seasonal weather. Although the numbers were insufficient to conduct statistical tests, a trend in similarity between spring precipitation and choke prevalence was seen. Because years with higher spring precipitation apparently corresponded to higher choke prevalence, further investigation of an ability of spring precipitation to predict choke prevalence may be a valuable course of future study.

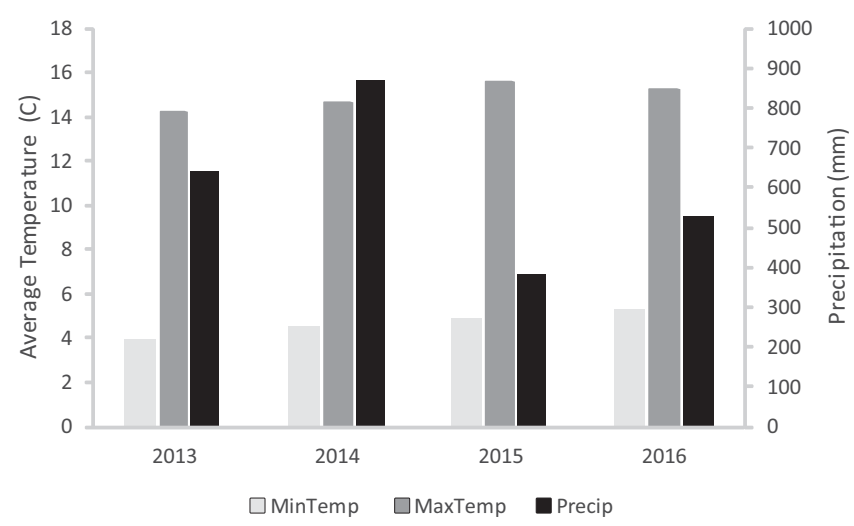

Fig. 3. Mean minimum and maximum temperatures, and sum of precipitation, for the months of March to May in Linn County, OR, for 4 years. 
The Corvallis location had a higher percentage of choke than the Albany location in 2013, a smaller rise of choke incidence in 2014, and a lower prevalence of choke than the Albany location in 2016 (Fig. 2). Interestingly, the two locations were separated by approximately $25 \mathrm{~km}$, and the Corvallis location had a history of choke incidence in adjacent fields, yet the Corvallis location exhibited a lower overall choke prevalence after 2013. One reason for this difference may have been poorer stand health at the Corvallis location. The average mortality per plot at the Corvallis location was $28 \%$, significantly higher than the $13 \%$ mortality of the Albany location $(P=0.02)$. The higher mortality corresponded to higher weed pressure and open space among plants in the Corvallis location. Previously, another assessment of choke also found that poorer stand

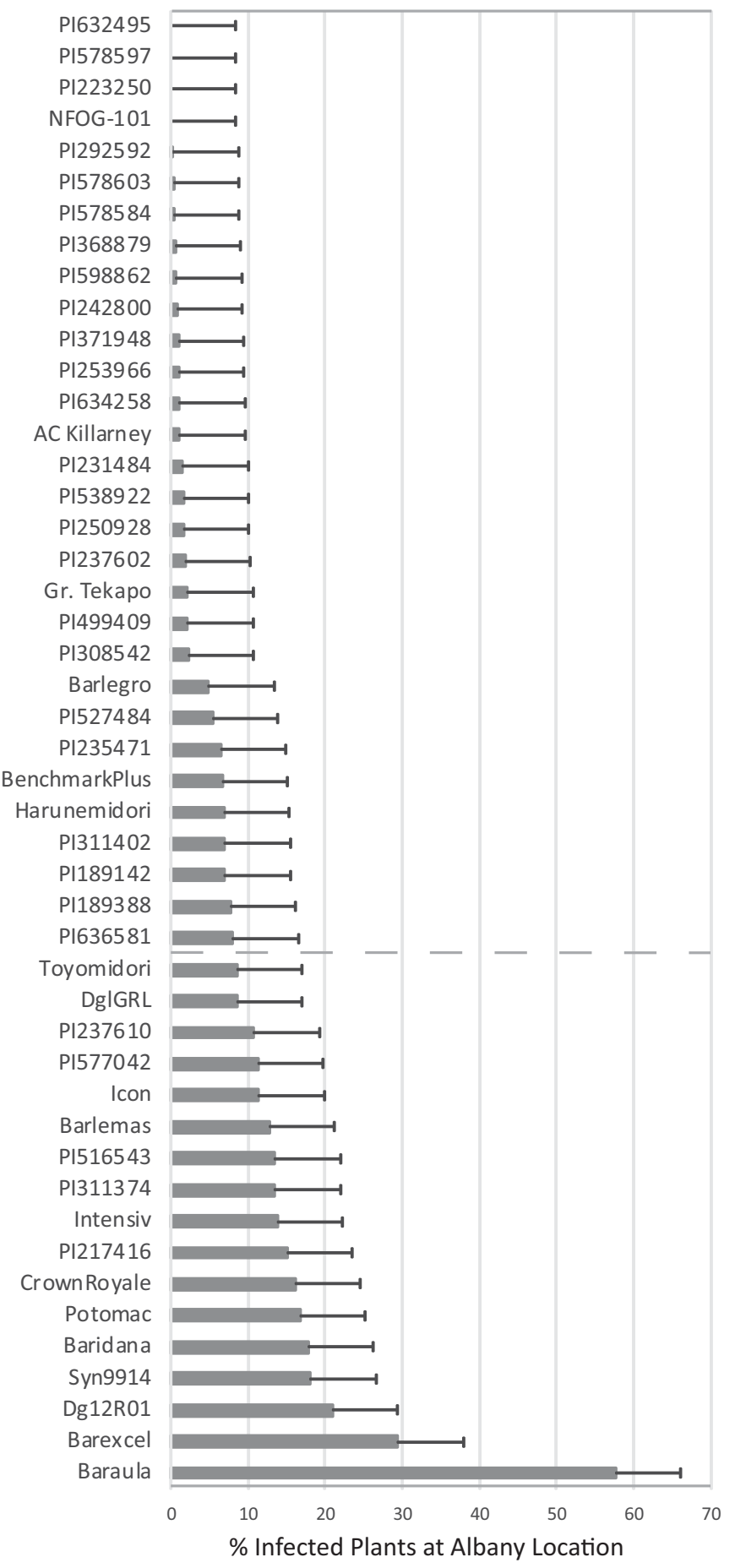

health coincided with less choke prevalence (Western and Cavett 1959).

It is possible that late flowering orchardgrass entries may avoid optimal fungal growth conditions in spring or that orchardgrass entries with either early or late swathing dates may avoid times of high ascospore flow (Western and Cavett 1959). However, choke prevalence was not correlated with either heading or swathing dates, nor was it able to discriminate among early or late heading or swathing entries. For example, AC Killarney and Baraula are both late-heading cultivars of orchardgrass, with the former showing the lowest choke prevalence among cultivars, whereas the latter showed the highest prevalence (Fig. 4). In a similar vein, early heading orchardgrass entries were found with both low and high choke prevalence.

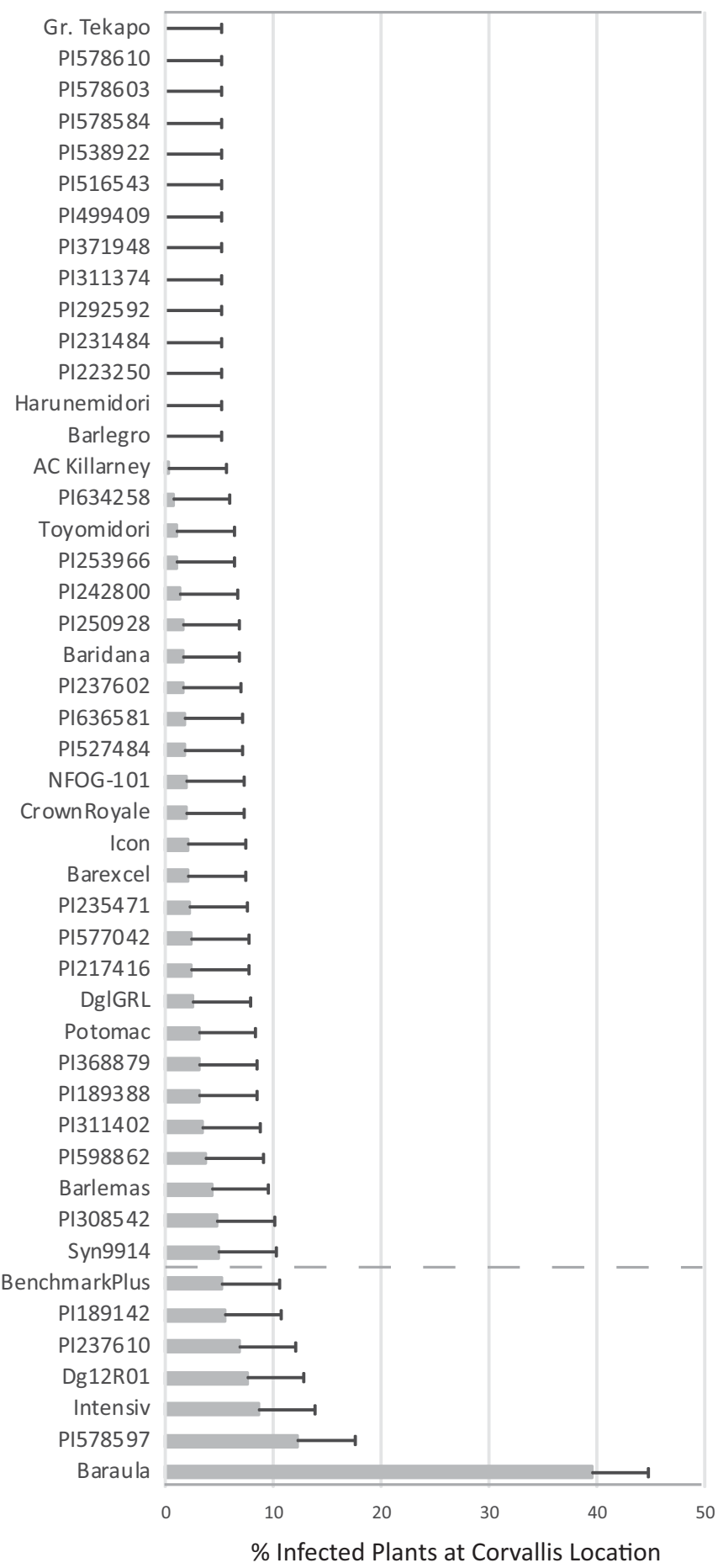

Fig. 4. Percent of Epichloë typhina-infected orchardgrass plants within entries at two locations in western Oregon, U.S.A. Error bars represent least significant difference values at $P=0.05$, and the dashed lines correspond to the threshold after which entries had significantly more choke than zero. 
One reason for the lack of association of swathing dates in particular might be that $E$. typhina ascospores are released over an extended period of time (Western and Cavett 1959), which likely encompassed the entire range of swathing dates. It would therefore be unlikely that seed producers could avoid swathing during high spore counts at seed harvest. From a plant-breeding perspective, however, these data do suggest that choke-tolerant orchardgrass varieties could be developed across heading or swathing dates.

In this study, the climate in western Oregon did not favor summer dormant/winter active Mediterranean ecotypes of orchardgrass, but several such entries were included and persisted through the experiment. In contrast to heading and swathing dates, there was partial evidence for an ability of choke prevalence to discriminate Mediterranean and unknown ecotypes of orchardgrass from Continental ecotypes, but not vice versa (Table 3 ). There was a preponderance of Mediterranean and unknown entries with low choke prevalence, whereas Continental ecotypes were evenly spread across the range of prevalence (Table 1, Fig. 4), which suggests that choke-

Table 3. Discriminant analysis for the ability of choke prevalence on orchardgrass at the Albany and Corvallis locations to distinguish among Continental, Mediterranean, and unknown orchardgrass ecotypes

\begin{tabular}{lcccr}
\hline & \multicolumn{4}{c}{ To } \\
\cline { 2 - 5 } From & Continental & Mediterranean & Unknown & Total \\
\hline Continental & 10 & 13 & 10 & 33 \\
Mediterranean & 0 & 3 & 4 & 7 \\
Unknown & 0 & 0 & 6 & 6 \\
Total & 10 & 16 & 20 & 46 \\
\hline
\end{tabular}

Table 4. Mating type frequency of Epichloë typhina-infected orchardgrass at two field locations ${ }^{\mathrm{a}}$

\begin{tabular}{llrrr}
\hline Year & Location & \multicolumn{1}{c}{$\boldsymbol{N}$} & \multicolumn{1}{c}{ MTA } & \multicolumn{1}{c}{ MTB } \\
\hline 2014 & Albany & 81 & $32(40 \%)$ & $49(60 \%)$ \\
& Corvallis & 48 & $20(42 \%)$ & $28(58 \%)$ \\
2015 & Albany & 165 & $84(51 \%)$ & $81(49 \%)$ \\
& Corvallis & 41 & $20(49 \%)$ & $21(51 \%)$ \\
2016 & Albany & 225 & $123(55 \%)$ & $102(45 \%)$ \\
\hline
\end{tabular}

${ }^{a}$ Mating type is based on presence of $m t A C$ for mating type A (MTA) and $m t B A$ for mating type B (MTB). tolerant cultivars can be developed from both Continental and Mediterranean ecotypes of orchardgrass.

Characterization of endophytes with PCR markers used to identify the potential of a strain to produce known alkaloids has provided insight into collections of native and forage grasses (Charlton et al. 2014; Shymanovich et al. 2017; Young et al. 2014). Consistent with previously analyzed E. typhina from orchardgrass (Schardl et al. 2012), the endophyte-infected orchardgrass from Oregon did not exhibit PCR products from genes involved in loline, ergot alkaloid, or indole-diterpene biosynthesis. Although one of the markers that correlates with peramine biosynthesis was present, all strains lacked the region that encodes the perA reductase domain and, therefore, would likely not be able to produce peramine (Berry et al. 2015). These results confirm earlier findings and show that orchardgrass infected with choke-causing E. typhina lacked the known endophyte-synthesized alkaloid products.

E. typhina is a heterothallic species that requires the opposite mating type to complete the sexual cycle, which results in the release of ascospores for horizontal transmission (Leuchtmann and Schardl 1998). Evaluation of the E. typhina strains across the two locations showed that both mating types were present in approximately equal abundance, consistent with the requirement of stromata fertilization. Interestingly, when multiple choked tillers were tested from a single plant, both mating types were sometimes found. Although it is still unclear when and how an orchardgrass plant is infected, our data indicate that a mature plant with multiple crown meristems could have different areas of the crown infected by different ascospores, possibly at the same or different times. This situation would usually be difficult to detect in a field setting, in which it can be hard to delineate the crown of a single plant in a sward, but in this study each plant was established from a single seed as spaced plants. Further evaluation of the samples with markers such as simple sequence repeats would be needed to better estimate endophyte variation.

The PI 578603 and PI 578584 Mediterranean ecotype accessions and the Continental ecotype accessions PI 223250, PI 538922, and PI 371948 showed little or no choke prevalence at both locations. Of the cultivars included in this study, AC Killarney, Grasslands Tekapo, and Barlegro showed the least overall choke prevalence, whereas Baraula, Barlemas, and Intensiv had the highest overall choke prevalence. The high level of choke found in Baraula in particular presents an optimal cultivar to further examine choke infection and growth in orchardgrass. Although careful consideration of other agronomic factors will be necessary to include these potentially choke-tolerant accessions into orchardgrass breeding schemes, these

Table 5. Evaluation of individual orchardgrass plants tested in both 2015 and 2016 for mixed infection based on the presence of both mating types

\begin{tabular}{|c|c|c|c|c|c|c|}
\hline \multirow[b]{2}{*}{ Plant line } & \multicolumn{3}{|c|}{ Number of choked plants } & \multirow[b]{2}{*}{ MTA $^{\mathbf{b}}$} & \multirow[b]{2}{*}{ MTB $^{\mathbf{b}}$} & \multirow[b]{2}{*}{$\operatorname{Mix}(\text { MTA and MTB })^{b}$} \\
\hline & 2015 & 2016 & Both $^{\mathbf{a}}$ & & & \\
\hline$\overline{\text { Baraula }}$ & 28 & 43 & 22 & 5 & 8 & 9 \\
\hline Barexcel & 18 & 18 & 13 & 6 & 5 & 2 \\
\hline syn9914 & 7 & 16 & 7 & 5 & 2 & 0 \\
\hline Potomac & 13 & 13 & 7 & 5 & 2 & 0 \\
\hline Dg12R01 & 9 & 12 & 6 & 3 & 2 & 1 \\
\hline Baridana & 11 & 10 & 6 & 3 & 0 & 3 \\
\hline PI 237610 & 7 & 7 & 6 & 1 & 3 & 2 \\
\hline Crown Royale & 7 & 9 & 5 & 3 & 0 & 2 \\
\hline Intensiv & 6 & 10 & 5 & 4 & 0 & 1 \\
\hline PI 217416 & 6 & 16 & 4 & 1 & 2 & 1 \\
\hline Icon & 6 & 7 & 4 & 1 & 3 & 0 \\
\hline PI 577042 & 4 & 7 & 4 & 2 & 1 & 1 \\
\hline Toyomidori & 6 & 5 & 4 & 1 & 3 & 0 \\
\hline Barlemas & 4 & 6 & 3 & 1 & 1 & 1 \\
\hline PI 527484 & 2 & 6 & 1 & 1 & 0 & 0 \\
\hline PI 189388 & 1 & 9 & 1 & 1 & 0 & 0 \\
\hline Total & $\ldots$ & $\ldots$ & 98 & $43(44 \%)$ & $32(33 \%)$ & $23(23 \%)$ \\
\hline
\end{tabular}

a The number of infected plants found in both 2015 and 2016.

${ }^{\mathrm{b}}$ Mating type is based on presence of $m t A C$ for mating type A (MTA) and $m t B A$ for mating type B (MTB); mix indicates both $m t A C$ and $m t B A$ were present in either 2015 or 2016 sample. Note: a single tiller only contains one mating type. 
accessions and cultivars present promising orchardgrass breeding material.

\section{Acknowledgments}

The authors thank Patrick Boren and Robert Schroeder from Crop Production Services for critical field management and data collection assistance and Steve Rohner for field space and support. We also thank Ginger Swoboda, Scott Hill, Trey Hale, Acie Warner, Lynne Jacobs, Erin Hubbard, Chakradhar Mattupalli, Mihwa Yi, Daniel Berry, and Simona Florea for assisting in tiller collection.

\section{Literature Cited}

Alderman, S. C. 2013. Survival, germination, and growth of Epichloë typhina and significance of leaf wounds and insects in infection of orchardgrass. Plant Dis. 97:323-328

Berry, D., Takach, J. E., Schardl, C. L., Charlton, N. D., Scott, B., and Young, C. A. 2015. Disparate independent genetic events disrupt the secondary metabolism gene perA in certain symbiotic Epichloë species. Appl. Environ. Microbiol. 81:2797-2807.

Butler, D. G., Cullis, B. R., Gilmour, A. R., and Gogel, B. J. 2009. ASReml-R Reference Manual, version 3. Queensland Department of Primary Industries and Fisheries, Brisbane, Australia.

Cagaš, B., and Macháč, R. 2012. Effect of some factors on the incidence of choke (Epichloë typhina) in grass seed stands in the Czech Republic. Plant Prot. Sci. 48:10-16.

Charlton, N. D., Craven, K. D., Afkhami, M. E., Hall, B. A., Ghimire, S. R., and Young, C. A. 2014. Interspecific hybridization and bioactive alkaloid variation increases diversity in endophytic Epichlö̈ species of Bromus laevipes. FEMS Microbiol. Ecol. 90:276-289.

Christensen, M. J., Bennett, R. J., Ansari, H. A., Koga, H., Johnson, R. D., Bryan, G. T., Simpson, W. R., Koolaard, J. P., Nickless, E. M., and Voisey, C. R. 2008. Epichloë endophytes grow by intercalary hyphal extension in elongating grass leaves. Fungal Genet. Biol. 45:84-93.

Craven, K. D., Hsiau, P. T. W., Leuchtmann, A., Hollin, W., and Schardl, C. L. 2001. Multigene phylogeny of Epichloe species, fungal symbionts of grasses. Ann. Mo. Bot. Gard. 88:14-34.

Doerge, T. G. H., Jackson, T. L., and Youngberg, H. 2000. Orchardgrass seed fertilizer guide-Western Oregon. Oregon State University, Corvallis.

Hoffman, G. D., and Rao, S. 2014. Fertilization of Epichloë typhina stromata by mycophagous slugs. Mycologia 106:1-7.

Kirby, E. J. M. 1961. Host-parasite relations in the choke disease of grasses. Trans. Br. Mycol. Soc. 44:493-503.

Large, E. C. 1954. Surveys for choke (Epichloe typhina) in cocksfoot seed crops, 1951-53. Plant Pathol. 3:6-11.

Leuchtmann, A., and Schardl, C. L. 1998. Mating compatibility and phylogenetic relationships among two new species of Epichlö̈ and other congeneric European species. Mycol. Res. 102:1169-1182.
Leyronas, C., and Raynal, G. 2008. Role of fungal ascospores in the infection of orchardgrass (Dactylis glomerata) by Epichloë typhina agent of choke disease. J. Plant Pathol. 90:15-21.

Li, C. J., Wang, Z. F., Chen, N., and Nan, Z. B. 2009. First report of choke disease caused by Epichloë typhina on orchardgrass (Dactylis glomerata) in China. Plant Dis. 93:673.

Pfender, W. F., and Alderman, S. C. 1999. Geographical distribution and incidence of orchardgrass choke, caused by Epichloë typhina, in Oregon. Plant Dis. 83: 754-758.

Pfender, W. F., and Alderman, S. C. 2003. Evaluation of postharvest burning and fungicides to reduce the polyetic rate of increase of choke disease in orchardgrass seed production. Plant Dis. 87:375-379.

Pfender, W. F., and Alderman, S. C. 2006. Regional development of orchardgrass choke and estimation of seed yield loss. Plant Dis. 90:240-244.

R Core Team. 2013. R: A Language and Environment for Statistical Computing. R Foundation for Statistical Computing, Vienna, Austria.

Rao, S., Alderman, S., Kaser, J., and Hoffman, G. 2012. Fertilization of Epichloë typhina in cultivated Dactylis glomerata by factors besides Botanophila flies. Pages 122-126 in: Epichloae, Endophytes of Cool Season Grasses: Implications, Utilization and Biology. C. A. Young, G. E. Aiken, R. L. McCulley. J. R. Stickland, and C. L. Schardl, eds. Samuel Roberts Noble Foundation, Ardmore, OK

Rao, S., and Baumann, D. 2004. The interaction of a Botanophila fly species with an exotic Epichlö fungus in a cultivated grass: Fungivore or mutualist? Entomol. Exp. Appl. 112:99-105.

SAS Institute. 2011. The SAS System for Windows. SAS Institute, Cary, NC.

Schardl, C. L., Balestrini, R., Florea, S., Zhang, D., and Scott, B. 2009. Epichloë endophytes: Clavicipitaceous symbionts of grasses. Pages 275-306 in: Plant Relationships. H. B. Deising, ed. Springer, Berlin, Germany.

Schardl, C. L., Young, C. A., Faulkner, J. R., Florea, S., and Pan, J. 2012 Chemotypic diversity of epichloae, fungal symbionts of grasses. Fungal Ecol. 5:331-344.

Shymanovich, T., Charlton, N. D., Musso, A. M., Scheerer, J., Cech, N. B., Faeth, S. H., and Young, C. A. 2017. Interspecific and intraspecific hybrid Epichloë species symbiotic with the North American native grass Poa alsodes. Mycologia 109:459-474.

Smith, K. F., and Casler, M. D. 2004. Spatial analysis of forage grass trials across locations, years, and harvests. Crop Sci. 44:56-62.

Stewart, A. V., and Ellison, N. 2010. The Genus Dactylis; Wealth of Wild Species: Role in Plant Genome Elucidation and Improvement, Vol. 2. Springer, New York, NY.

Western, J. H., and Cavett, J. J. 1959. The choke disease of cocksfoot (Dactylis glomerata) caused by Epichloe typhina (Fr.) Tul. Trans. Br. Mycol. Soc. 42: 298-307.

Young, C. A., Charlton, N. D., Takach, J. E., Swoboda, G. A., Trammell, M. A., Huhman, D. V., and Hopkins, A. A. 2014. Characterization of Epichloë coenophiala within the US: Are all tall fescue endophytes created equal? Front Chem. 2:95. 